\title{
PRELIMINARY PHYTOCHEMICAL SCREENING AND EVALUATION OF ANALGESIC AND MUSCLE RELAXANT ACTIVITY OF THE ETHANOLIC EXTRACT OF THE LEAVES OF MIRABILIS JALAPA
}

\author{
DEEPSIKHA BHARALI*, DIPANKAR SAHA \\ Girijananda Chowdhury Institute of Pharmaceutical, Science, Azara, Hatkhowapara, Guwahati 781017 \\ Email: deepy531@gmail.com
}

Received: 20 May 2017, Revised and Accepted: 22 Jul 2017

\begin{abstract}
Objective: The aim and objectives of the present work is to determine pharmacological activity upon ethnopharmacological survey. The present study deals with phytochemical screening and analgesic as well as muscle relaxant activity of leaves of Mirabilis jalapa.

Methods: The present study is aimed at phytochemical screening and evaluating the analgesic and muscle relaxant activities of ethanolic leaf extract of Mirabilis jalapa by using hot plate method and rota rod method respectively [1, 2]. The Phytochemical screening of the extract was done according to the standard procedures to reveal the presence of the active constituents like Alkaloids, flavonoids, phenols, glycosides, tannins, saponins, steroids, carbohydrates etc [3-5].

Results: The analgesic and muscle relaxant activity study were dose dependent. The EEMJ extracts $(100 \mathrm{mg} / \mathrm{kg}, 200 \mathrm{mg} / \mathrm{kg}, 500 \mathrm{mg} / \mathrm{kg})$ and the standard drug Diclofenac sodium ( $25 \mathrm{mg} / \mathrm{kg}$ ) shows significant increase in the reaction time when compared with control at $30 \mathrm{~min}, 60 \mathrm{~min}, 90 \mathrm{~min}$ and $120 \mathrm{~min}$ and the effect of standard was found to be highest during the study. Another study was designed to evaluate the skeletal muscle relaxant properties of ethanolic extract of leaves of Mirabilis jalapa. Linn by taking the EEMJ extracts (100 mg/kg, $200 \mathrm{mg} / \mathrm{kg}, 500 \mathrm{mg} / \mathrm{kg})$ and standard drug Lorzepam $(10 \mathrm{mg} / \mathrm{kg})$. Both the extracts and standard drug show decrease in the fall of time in a dose dependent manner when compared with control at $15 \mathrm{~min}, 30 \mathrm{~min}, 45 \mathrm{~min}$ respectively.
\end{abstract}

Conclusion: Therefore, from the above study it is revealed that Mirabilis jalapa showing better pharmacological activities (Analgesic and Muscle relaxant) in dose dependent manner.

Keywords: Mirabilis jalapa, Phytochemical screening, Analgesic, Muscle relaxant, Diclofenac sodium, Lorazepam

(C) 2017 The Authors. Published by Innovare Academic Sciences Pvt Ltd. This is an open access article under the CC BY license (http://creativecommons.org/licenses/by/4.0/) DOI: http://dx.doi.org/10.22159/ijcpr.2017v9i5.22144

\section{INTRODUCTION}

Mirabilis jalapa is a perennial herb. It is used in the traditional treatment of diseases. Alkaloids, flavonoids, phenols, glycosides, tannins, saponins, lignins, carbohydrates are the active constituents present in it. In conventional medicines, the plant is used in the treatment of skin diseases, carminative, cathartic purgative, stomachic, vermifuge properties, antiparasitic, wound healer, diuretic, anthelminic and urinary tract disorder. Mirabilis jalapa (MJ) commonly known as Four o'clock plant belonging to family Nyctaginaceae. It is known as Godhuli Gopal in Assamese [6]. Majority of the world population depend on Traditional Medicine such as herbs for treatment of various ailments. Present day medicines are derived from the herbal source. An analgesic or painkiller is any member of the group of drugs used to achieve analgesia. Analgesic drugs act in various ways on the peripheral and central nervous systems. They are distinct from anaesthetics, which temporarily affect, and in some instances completely eliminate sensation. Analgesics include paracetamol, the non-steroidal anti-inflammatory drugs(NSAIDs) such as the salicylates and opioid drugs such as morphine. Analgesic choice is also determined by the type of pain $[14,15]$. A muscle relaxant is a drug that affects skeletal muscle function and decreases the muscle tone. It may be used to alleviate symptoms such as muscle spasms, pain etc. The term "muscle relaxant"is used to refer to two major therapeutic groups: neuromuscular blockers and spasmolytics $[7,8]$.

\section{Analgesics}

An analgesic or painkiller is any member of the group of drugs used to achieve analgesia. Analgesic drugs act in various ways on the peripheral and central nervous systems. They are distinct from anaesthetics, which temporarily affected, and in some instances completely eliminate sensation. Analgesics include paracetamol, the non-steroidal anti-inflammatory drugs (NSAIDs) such as the salicylates and opioid drugs such as morphine. Analgesic choice is also determined by the type of pain $[14,15]$. Traditionally, pain has been divided into two classes, acute and chronic. Pain becomes a concerning focus of global scientific research due to its implication ranges not only human but also animal diseases. Opioids and nonsteroidal anti-inflammatory drugs (NSAIDs) are widely used to get relief from pain but overdoses may lead to life threatening side effects like respiratory depression, bradycardia, hypotension and long-term use of opoids may cause dependency and addiction. Statistics showed that the use of NSAIDs increases the risk of significant GI complications (eg, bleeding, hospitalization, surgery). These are also believed to cause a peptic ulcer and gastrointestinal bleeding $[9,10]$.

\section{Muscle relaxants}

A muscle relaxant is a drug that affects skeletal muscle function and decreases the muscle tone. It may be used to alleviate symptoms such as muscle spasms, pain etc. The term "muscle relaxant"is used to refer to two major therapeutic groups: neuromuscular blockers and spasmolytics. Neuromuscular blockers act by interfering with transmission at the neuromuscular end plate and have no central nervous system (CNS) activity.

They are often used during surgical procedures and in intensive care and emergency medicine to cause temporary paralysis. Spasmolytics, also known as "centrally acting" muscle relaxants, are used to alleviate musculoskeletal pain and spasms and to reduce spasticity in a variety of neurological conditions. While both neuromuscular blockers and spasmolytics are often grouped together as muscle relaxants, the term is commonly used to refer to spasmolytics only [11]

The aim of the present study is to perform the preliminary phytochemical screening and evaluation of analgesic and muscle relaxant activity of ethanolic extract of the leaves of the plant Mirabilis jalapa. 


\section{MATERIALS AND METHODS}

\section{Collection of plant material}

The whole plant with leaves, stems and roots was collected from village Sualkuchi area of Kamrup district of Assam in January 2017 and the plant was thoroughly washed with water. Roots and stems were discarded and the leaves were dried in shade for $3 \mathrm{w}$ and finally dried in a thermostatic oven at a considerably low temperature not exceeding $40^{\circ} \mathrm{C}$ for one hour.

\section{Authentication of plant material}

The plant was authenticated by Dr. P. P. Baruah, Professor and Head, Department of Botany, Gauhati University. A voucher specimen (Acc No.-18223, Dt: 22.03.2017) was kept in Department of Botany, Gauhati University for future reference.

\section{Drugs and chemicals}

The drugs Diclofenac sodium, Lorazepam and chemical 5\% CMC were used during the experimental study. All chemicals and reagents used for physicochemical evaluation and phytochemical screening were of analytical grade.

$>$ Petrolium ether $(95 \% \mathrm{v} / \mathrm{v})$

$>$ Specification: Boiling point $60-80^{\circ} \mathrm{C}$

$>$ Density: 0.664-0.671

$>$ Free acid: $<0.005 \%$

$>$ Ethanol(absolute)

> Assay(by volume): Minimum 99.9\%

$>$ Dragandroff reagent, Mayer's reagent, Molish's reagent, Fehling solution A and B, Sulphuric acid, Lead acetate, Sodium citrate, Copper sulphate, Ferric chloride, Sodium hydroxide, Glacial acetic acid, Benzene, Chloroform, Ammonia, Nitric acid, Potassium nitrite, Hydrochloric acid.

\section{Extract preparation}

Extraction of dried leaves powder of Mirabilis jalapa was done by successive extraction procedure. It is carried out using petroleum ether $(95 \% \mathrm{~V} / \mathrm{V})$ by maceration method at room temperature. $100 \mathrm{~g}$ of ground sample was taken in the round bottom flask $(500 \mathrm{ml})$. To that above flask 1 litre of pet. Ether was poured and was kept aside under cold maceration technique for about $7 \mathrm{~d}$ with intermittent shaking. On the final day, it was strained and pressed. After that, the expressed liquids were added to the strained liquids and the combined liquids were clarified by filtration first through a muslin cloth and then with filter paper. The liquid extract was then distilled off and the remaining solvent was allowed to evaporate in a water bath at a constant temperature. Then it was poured in a tarred Petri dish was dried for several days. The concentrated extract was then weighed and the percentage yield was calculated and finally stored in air tight container. The marc obtained after filtration again kept in an RBF and pour again 1litre of Ethanol and the flask was air tightened and kept it for another $7 \mathrm{~d}$. The above process is repeated for ethanolic extract also and the yield ethanolic extract was kept in a Petri dish in air tight condition and finally kept it in air tight container. Thus total ethanolic extract is obtained which was used for an investigation [12].

\section{Experimental animals}

Swiss albino mice aged 8-10 w (25-30 gm) were used for the experimental study, breed and reared at the animal house of the institution (Girijananda Chowdhury Institute of Pharmaceutical Science). The animals were acclimatized to the laboratory conditions (room temperature $24 \pm 2{ }^{\circ} \mathrm{C}$, relative humidity 55-60\%, and $12 \mathrm{~h}$ light and dark cycles) and kept in plastic cages. These animals were fed standard pellet diet and water ad libitum. Food was withdrawn $12 \mathrm{~h}$ before and during the experimental hours.

\section{Phytochemical screening}

All the phytochemical tests were done by taking the reference of the standard method to detect the presence or absence of chemical constituents [3-5].

\section{Analgesic activity}

This test was carried out based on the method described by Eddy and Leimback (1953) i.e., Hot plate method. The animals were positioned on a hot plate kept at a temperature of $\left(55 \pm 0.5^{\circ} \mathrm{C}\right)$. A cut off period of 15 seconds was observed to avoid damage to the paw. Reaction time was recorded when animals licked their fore or hind paws or jumped prior to and record the stay time on hot plate at 30 min, $60 \mathrm{~min}, 90 \mathrm{~min}$ and $120 \mathrm{~min}$ after oral administration of the samples for each group of animals. The animals were grouped accordingly as follows-

Group I-Saline water ( $10 \mathrm{ml} / \mathrm{kg}$, p. o.) as control-----5 animals, Group IIDiclofenac sodium $(25 \mathrm{mg} / \mathrm{kg}$, p. o.) as standard drug---5 animals, Group III-Ethanolic extract of Mirabilis jalapa leaves $(100 \mathrm{mg} / \mathrm{kg} \mathrm{b} . \mathrm{w}$, orally) Test 1-----5 animals, Group IV-Ethanolic extract of Mirabilis jalapa leaves (200 mg/kg b. w, orally) Test 2-----5 animals, Group V-Ethanolic extract of Mirabilis jalapa leaves ( $500 \mathrm{mg} / \mathrm{kg} \mathrm{b.} \mathrm{w}$, orally).

Test 3-----5 animals.

\section{Muscle relaxant}

It was performed by rota rod method. The apparatus consists of a horizontal wooden rod or metal rod coated with rubber with $3 \mathrm{~cm}$ diameter attached to a motor with the speed adjusted to 2 rotations per minute. The rod is $75 \mathrm{~cm}$ in length and is divided into 6 sections by plastic discs, thereby allowing the simultaneous testing of 6 mice. The rod is in a height of about $50 \mathrm{~cm}$ above the table top in order to discourage the animals from jumping off the roller. Cages below the sections serve to restrict the movements of the animals when they fall from the roller. Mice with a weight between 20 and $30 \mathrm{~g}$ undergo a pretest on the apparatus. Only those animals which have demonstrated their ability to remain on the revolving rod for at least 1 minute are used for the test. The test compounds are administered intraperitoneally or orally. The number of animals falling from the roller during this time is counted. Using different doses, ED50 values can be calculated. Moreover, testing at various time intervals lke 15, 30 and $45 \mathrm{~min}$, the time-response curves can be obtained. The animals were grouped as follows-

Group I-Saline water $(10 \mathrm{ml} / \mathrm{kg}, \mathrm{p}$. o. $)$ as negative control-----5 animals

Group II-Lorzepam (10 mg/kg, p. o.) as positive control, standard drug-----5 animals

Group III-Ethanolic extract of Mirabilis jalapa leaves $(100 \mathrm{mg} / \mathrm{kg}$ b. w, orally) -----5 animals

Group IV-Ethanolic extract of Mirabilis jalapa leaves $(200 \mathrm{mg} / \mathrm{kg} \mathrm{b}$. w, orally) -----5 animals

Group V-Ethanolic extract of Mirabilis jalapa leaves $(500 \mathrm{mg} / \mathrm{kg} \mathrm{b}$. w, orally) -----5 animals.

\section{RESULTS}

Phytochemical screening

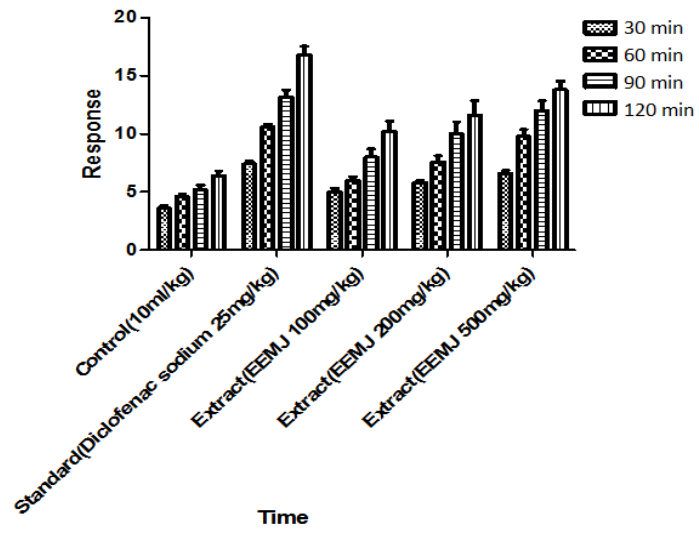

Fig. 1: Analgesic activity by hot plate method in mice (Response. Vs time). 
Table 1: Table for phytochemical screening

\begin{tabular}{|c|c|c|}
\hline Constituents & Test & Ethanolic extract \\
\hline \multirow[t]{4}{*}{ Alkaloid } & 1)Meyer's test & $+(\mathrm{ve})$ \\
\hline & 2)Hager's test & $+(\mathrm{ve})$ \\
\hline & 3)Wagner's test & $+(\mathrm{ve})$ \\
\hline & 4)Dragandraff's test & $+(\mathrm{ve})$ \\
\hline \multirow[t]{2}{*}{ Carbohydrate } & 1)Fehling test & $+(\mathrm{ve})$ \\
\hline & 2)Molisch test & $+(\mathrm{ve})$ \\
\hline \multirow[t]{2}{*}{ Protein } & 1)Millon's test & $+(\mathrm{ve})$ \\
\hline & 2)Biuret test & $+(\mathrm{ve})$ \\
\hline \multirow[t]{5}{*}{ Glycosides } & a)Cardiac glycoside & \\
\hline & 1)Legal test & $-(\mathrm{ve})$ \\
\hline & 2)Killer-kiliani test & $+(\mathrm{ve})$ \\
\hline & b)Anthraquinone glycoside & $+(\mathrm{ve})$ \\
\hline & c)Saponine glycoside & $+(\mathrm{ve})$ \\
\hline Flavanoids & 1)Shinoda test 2)Lead acetic test & $+(\mathrm{ve})+(\mathrm{ve})$ \\
\hline Tannin & 1)Gelatin test & $+(\mathrm{ve})$ \\
\hline Steroids & 1)Liberman-burchard reaction 2)Salkowski reaction & $+(\mathrm{ve})+(\mathrm{ve})$ \\
\hline Phenols & 1)Ferric chloride test & $+(\mathrm{ve})$ \\
\hline
\end{tabular}

Present (+), Absent (-)

Analgesic activity

Table 2: Analgesic activity by hot plate method in mice

\begin{tabular}{|c|c|c|c|c|c|c|}
\hline \multirow[t]{2}{*}{ Group } & \multirow[t]{2}{*}{ Treatment } & \multirow[t]{2}{*}{ Dose } & \multicolumn{4}{|c|}{ Reaction time in seconds at time (minutes) (mean \pm sem) } \\
\hline & & & $30 \mathrm{~min}$ & $60 \mathrm{~min}$ & $90 \mathrm{~min}$ & $120 \mathrm{~min}$ \\
\hline Control & Normal saline & $10 \mathrm{ml} / \mathrm{kg}$ & $3.600 \pm 0.245$ & $4.600 \pm 0.245$ & $5.200 \pm 0.374$ & $6.400 \pm 0.400$ \\
\hline Standard & Diclofenac sodium & $25 \mathrm{mg} / \mathrm{kg}$ & $7.400 \pm 0.245$ & $10.600 \pm 0.245$ & $13.200 \pm 0.583$ & $16.800 \pm 0.735$ \\
\hline \multirow[t]{3}{*}{ Extract } & 1)EEMJ & $100 \mathrm{mg} / \mathrm{kg}$ & $5.000 \pm 0.316$ & $6.000 \pm 0.316$ & $8.000 \pm 0.707$ & $10.200 \pm 0.917$ \\
\hline & 2)EEMJ & $200 \mathrm{mg} / \mathrm{kg}$ & $5.800 \pm 0.200$ & $7.600 \pm 0.510$ & $10.000 \pm 1.049$ & $11.600 \pm 1.288$ \\
\hline & 3)EEMJ & $500 \mathrm{mg} / \mathrm{kg}$ & $6.600 \pm 0.245$ & $9.800 \pm 0.583$ & $12.000 \pm 0.837$ & $13.800 \pm 0.735$ \\
\hline
\end{tabular}

Each value is the mean \pm SEM for 5 mice, EEMJ= Ethanolic extract of mirabilis jalapa. Extracts were compared with control. Data were analyzed by using Two-way ANOVA.

Muscle relaxant activity

Table 3: Muscle relaxant activity by rota rod method in mice

\begin{tabular}{|c|c|c|c|c|c|}
\hline \multirow[t]{2}{*}{ Group } & \multirow[t]{2}{*}{ Treatment } & \multirow[t]{2}{*}{ Dose group } & \multicolumn{3}{|c|}{ Reaction time in seconds at time (min) (mean \pm sem) } \\
\hline & & & $15 \min$ & $30 \mathrm{~min}$ & $45 \mathrm{~min}$ \\
\hline Control & Normal saline & $10 \mathrm{ml} / \mathrm{kg}$ & $49.600 \pm 1.691$ & $46.400 \pm 1.288$ & $44.400 \pm 1.077$ \\
\hline Standard & Lorazepam & $10 \mathrm{mg} / \mathrm{kg}$ & $6.200 \pm 0583$ & $5.000 \pm 0.447$ & $4.600 \pm 0.510$ \\
\hline \multirow[t]{3}{*}{ Extract } & 1)EEMJ & $100 \mathrm{mg} / \mathrm{kg}$ & $8.400 \pm 0.510$ & $6.600 \pm 0.245$ & $4.600 \pm 0.600$ \\
\hline & 2)EEMJ & $200 \mathrm{mg} / \mathrm{kg}$ & $3.800 \pm .0490$ & $3.400 \pm 0245$ & $2.600 \pm 0.400$ \\
\hline & 3)EEMJ & $500 \mathrm{mg} / \mathrm{kg}$ & $2.800 \pm 0.374$ & $2.400 \pm 0.245$ & $1.800 \pm 0.374$ \\
\hline
\end{tabular}

Each value is the mean \pm SEM for 5 mice, EEMJ= Ethanolic extract of mirabilis jalapa. The extracts were compared with control. Data were analyzed by using Two-way ANOVA.

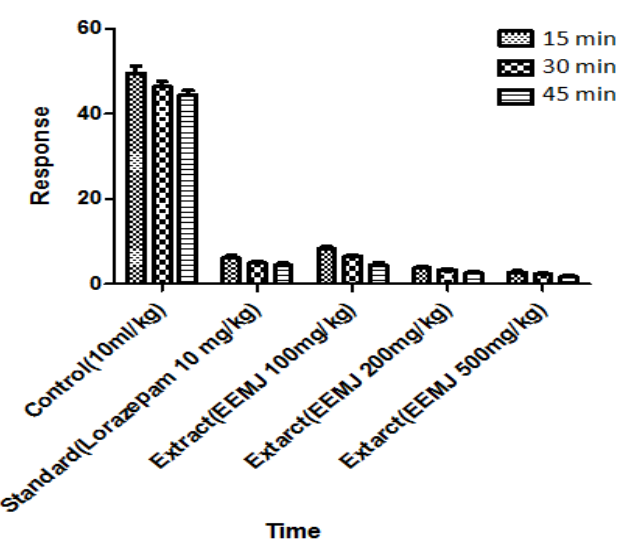

Fig. 2: Muscle relaxant activity by rota rod method in mice (Response Vs time)

\section{DISCUSSION}

To have further descriptive knowledge regarding the plant, I have done certain experimental works by using the leaves of Mirabilis jalapa.

I have performed Phytochemical screening to check the various phytochemical constituents present in Mirabillis jalapa by using the Ethanolic extract of the coarsely powdered dried leaves and from the experimental study I found that it contains Alkaloids, Carbohydrates, Phenols, Tannins, Flavonoids, Glycosides, Steroids as the active phytochemical constituents. All the constituents are meant for the various medicinal activities that are shown by the plant.

A pharmacological screening test for Mirabilis jalapa was performed to check the analgesic activity of the plant. The ethanolic extract of Mirabilis jalapa leaf (EEMJ) significantly increase the reaction time at different doses. $10 \mathrm{ml} / \mathrm{kg}$ saline water was served to each animals in control(Group I), and it is taken as the reference to make a comparision between the extracts of different concentration at 
different time intervals at $30 \mathrm{~min}, 60 \mathrm{~min}, 90 \mathrm{~min}$ and $120 \mathrm{~min}$. All the drugs were administered orally. First group serves as control (Saline water $10 \mathrm{ml} / \mathrm{kg}$ ), second group of animals served as standard control (Standard Drug: $25 \mathrm{mg} / \mathrm{kg}$ Diclofenac sodium), while group 3,4 and 5 received extracts (EEMJ) $100 \mathrm{mg} / \mathrm{kg}, 200 \mathrm{mg} / \mathrm{kg}$ and 500 $\mathrm{mg} / \mathrm{kg}$ respectively. At $30 \mathrm{~min}, 60 \mathrm{~min}, 90 \mathrm{~min}$ and $120 \mathrm{~min}$ there is a significant increase in the reaction time in both standards and all doses of the extracts as shown in the fig. 2 respectively. The highest response is shown by the standard drug and among the extracts, the highest response is seen in case of the extract $500 \mathrm{mg} / \mathrm{kg}$. The hot plate method as described by Eddy and Leimback (1953) is the most common thermal nociception model used for evaluating the central analgesic efficacy of drugs or compounds. This method can be considered to be selective for the centrally acting analgesics, that they could have centrally acting analgesic property and the Ethanolic extract of leaves of Mirabilis jalapa plant gives a positive test. It is observed that at $500 \mathrm{mg} / \mathrm{kg}$ the reaction time is increased the most according to time and dose dependent manner. Therefore increase in the reaction time indicates that the ethanolic extract of leaves of Mirabilis jalapa shows significant analgesic activity by comparing with the control group.

Another study was designed to evaluate the skeletal muscle relaxant properties of ethanolic extract of leaves of Mirabilis jalapa. Linn. In this test, the ethanolic extract of leaves of Mirabilis jalapa $100 \mathrm{mg} / \mathrm{kg}, 200$ $\mathrm{mg} / \mathrm{kg}$ and $500 \mathrm{mg} / \mathrm{kg}$ significantly reduced time spent on the revolving rod by the animals. Here First group serves as control (Saline water 10 $\mathrm{ml} / \mathrm{kg}$ ), second group of animals served as standard control (Standard drug: $10 \mathrm{mg} / \mathrm{kg}$ Lorazepam), while group 3, 4 and 5 received extracts (EEM) $100 \mathrm{mg} / \mathrm{kg}, 200 \mathrm{mg} / \mathrm{kg}$ and $500 \mathrm{mg} / \mathrm{kg}$ respectively. The fall of time gradually decreased according to a dose that is fall of time is dose dependent. The resultant decrease in the time of fall was shown by the extract $500 \mathrm{mg} / \mathrm{kg}$ at the time period of $45 \mathrm{~min}$ than that of the other extracts. The standard drug also showed a significant effect when compared to control. The effect of extract at the dose of $500 \mathrm{mg} / \mathrm{kg}$ is found to be the highest. Therefore it can be concluded that the ethanolic extract of leaves of Mirabilis jalapa shows muscle relaxant property on dose dependent manner compared with control. Therefore, from the above study, it is examined that Mirabilis jalapa showing better pharmacological activities in dose dependent manner (Analgesic and muscle relaxant activity) Further studies may be performed on this herbal medicinal plant to know about the various effects, the potentiality of the plant and their role in curing various diseases.

\section{CONCLUSION}

The ethanolic extract of leaves of Mirabilis jalapa was found to possess several bioactive constituents like Alkaloids, Flavonoids, Phenol, Steroids, Tannins, Glycosides as the active phytochemical constituents associated with potent pharmacological activities as shown in the result above. During the course of study, I have found that the ethanolic extract of dried leaves of Mirabilis jalapa has shown considerable analgesic and muscle relaxant activity as compared to control. Therefore it's ethnomedical claims were so true according to the above experimental results. This gives support to the claim for the traditional use of the plant in the treatment of acute pain and muscle spasm.

Therefore, use of modern technology and further studies need to be done for the isolation and identification of the active principle which is responsible for these activities which can further give rise to new drug molecule.

\section{CONFLICT OF INTERESTS}

\section{Declare none}

\section{REFERENCES}

1. Cartmell SM, Gelgor L, Mitchell D. A revised rota rod procedure for measuring the effect of antinociceptive drugs on motor function in the rat. J Pharmacol Meth 1991;26:149-59.

2. Lekshmi RN, Manjunath KP, Savadi RV, Akki KS Antiinflammatory activity of Mirabilis jalapa Linn leaves. J Basic Clin Pharm 2010;1:93-6.

3. Kokate CK, Purohit AP, Gokhale SB. Pharmacognosy. 8th ed. India: Nirali Prakashan; 2002. p. 154-272.

4. Evans WC, Trease, Evans. Pharmacognosy. $15^{\text {th }}$ ed. Toronto: Harcourt Pub Ltd; 2002. p. 1-40.

5. Khandelwal KR. Practical pharmacognosy techniques and experiments. India: Nirali Prakashan; 2010. p. 12, 30-12, 32.

6. Adimoelja A. Phytochemicals and breakthrough of traditional herbs in the management of sexual dysfunction. Int J Androl 2000;23:82-4.

7. Akerele 0 , Olayiwola V. Nature's medicinal bounty: don't throw it away. W H Forum 1993;2:390-5.

8. Colixto JB, Rafeeq AK, Ahmed S, Aslam M. Efficacy, safty, quality control, marketing and regulatory guidelines for herbal medicines. Braz J Med Biol Res 2000;33:179-89.

9. Adeolu A, Sunday 00. Anti-inflammatory and analgesic activities of the soft drink leaf extract of Phyllanthus amarus in some laboratory animals. Br Biotechnol J 2013;3:191-204.

10. Lee SH, Han CD, Yang $\mathrm{IH}, \mathrm{Ha}$ CW. Prescription pattern of NSAIDs and the prevalence of NSAID-induced gastrointestinal risk factors of orthopedic patients in clinic practice in Kore. J Korean Med Sci 2011;26:561-7.

11. Raghavendra T. Neuromuscular blocking drugs: discovery and development. J Royal Soc Med 2002;95:363-7.

12. Ncube NS, Afolayan AJ, Okoh AI. Assessment techniques of antimicrobial properties of natural compounds of plant origin: current methods and future trends. Afr J Biol 2008;7:1797-806.

\section{How to cite this article}

- Deepsikha Bharali, Dipankar Saha. Preliminary phytochemical screening and evaluation of analgesic and muscle relaxant activity of the ethanolic extract of the leaves of Mirabilis jalapa. Int J Curr Pharm Res 2017;9(5):81-84. 